\title{
Application of the SWAT Model for River Flow Forecasting in Sri Lanka*
}

\author{
H. A . Prasantha HAPUARACHCHI ${ }^{1}$, \\ LI Zhijia $^{1} \&$ Flügel Albert WOLFGANG ${ }^{2}$ \\ (1: College of Water Resources and Environment, Hohai University, Nanjing 210098, P.R. China; \\ 2: International Water Management Institute, Battaramulla, Sri Lanka)
}

\begin{abstract}
In the present study, the SWAT model and the Xinanjiang model have been used for daily flow forecasting of the Kalu River upper catchment in Sri Lanka. Kalu River is the second largest river in Sri Lanka and due to heavy rainfalls over the catchment, steep river slopes with narrow valleys in the upper catchment and mild riverbed slopes with wide and flat plains in the middle and lower catchments, the floods in Kalu River basin have become regular. The SWAT model has been used for daily river flow predictions in the Kalu River, and compared with the results obtained using the Xinanjiang model. In this study, the Xinanjiang model has performed slightly better than the SWAT model for forecasting the daily flow of Kalu River. In fact it might be partly attributable due to the poor quality and inadequate data, since the output of the SWAT (distributed model) strictly depends on the quality of input data. In addition, many people in Sri Lanka use well water for their domestic purposes. When considering a catchment as a whole, normally it is a very large area, and therefore it is not possible to record or count all the individual minor scale water utilizations in detail such as small irrigation, animal husbandry in minor scale and industrial water utilizations in minor scale. The cumulative value of such water utilizations might be large. The absence of these data may specially affect the distributed models in water balancing. But the conceptual watershed models (e.g. Xinanjiang model) are capable of adjusting their parameters while calibrating, according to the situation since most of their parameters have no physical background. As a result conceptual watershed models show better performance than distributed models where the catchment characteristics and model inputs are limited or incomplete.
\end{abstract}

Keywords: Xinanjiang model, SWAT model, conceptual watershed models, distributed watershed models, river flow forecasting

In the present study, the SWAT model ${ }^{[1]}$ and the Xinanjiang model ${ }^{[2-3]}$ have been used for daily river flow forecasting of the Kalu River upper catchment in Sri Lanka. Kalu River is the

*Supported by the International Water Management Institute (IWMI).

Received:2003-08-01;Accepted:2003-12-17. H. A. Prasantha HAPUARACHCHI, male, Ph.D, email: hapuara@yamanashi.ac.jp. 
second largest river in Sri Lanka. Basically Sri Lanka receives rainfall in two monsoon seasons. Due to its geographical location, Kalu river catchment receives rain during both of these monsoon seasons. Average annual rainfall of the overall catchment is around $4000 \mathrm{~mm}$ and it ranges from $2750 \mathrm{~mm}$ in coastal areas to $5000 \mathrm{~mm}$ in mountainous areas. Since the catchment is entirely situated in the wet zone, it has a high rainfall to runoff response. This high volume of water often discharges as floods. Floods result in damage to houses, property and even lives.

Severe environmental problems such as deforestation and soil erosion can be seen in this catchment due to 'Chena' cultivation and gem mining. In normal practice of 'Chena' cultivation, farmers destroy a part of forest by burning and cultivate tropical plants. After some years, when the land becomes non-arable, they move to another place and practice the same. Due to 'Chena' cultivation, tree felling on an extensive scale and the periodic replanting of tea and rubber plantations, the upper slopes of the catchment are not stable and landslides can be seen often. Also Kalu river upper catchment is popular for gem mining. Normally gem-bearing gravels occur in beds or pockets and are found $2-20 \mathrm{~m}$ beneath the surface. Gem bearing gravels show horizontal extensions and therefore horizontal tunneling is resorted to when mining. Some times these tunnels are several kilometers long and a causative factor for land subsidence in later time. Besides this, there are many environmental problems that could be attributed to gem mining. Sedimentation of clay minerals in rivers and tanks, lowering the ground water table, slope instability, limiting the extent of cultivable land and reducing yield due to soluble minerals which are products of gemming such as calcium, magnesium, potassium, and mosquito breading in abandoned pits are some of these problems. Considering these factors, it is important to model the Kalu river upper catchment to identify future environmental hazards. In the present study, the SWAT model has been applied to generate daily flows in the Kalu river upper catchment to identify in the catchment hydrological responses. The Xinanjiang model (a conceptual rainfall runoff model) has also been applied to forecast the daily flows and to compare its results with the SWAT model.

\section{SWAT model}

SWAT model ${ }^{[1]}$ was developed by the Agricultural Research Service (ARS) of the US Department of Agriculture (USDA). It was developed to predict the impact of land management practices on water, sediment and agricultural chemical yields in large complex watersheds with varying soils, land use and management conditions over long periods of time. Application of the model requires detailed information about weather, soil properties, topography, vegetation, and land management practices in watershed. SWAT is capable of handling water movement, sediment movement, crop growth, and nutrient cycling with the above information. In the present study, only the hydrologic processes of SWAT are considered. It is not possible to give a complete explanation about the SWAT model in this document. A detailed description of the SWAT model and user manual can be found in the web site http://www.brc.tamus.edu/swat/ or Neitsch et $a 1^{[1]}$. 


\section{Xinanjiang model}

Xinanjiang rainfall-runoff model ${ }^{[2-3]}$ is a conceptual watershed model developed at Hohai University, China in 1970s.It provides an integral structure, statistically describing the non-uniform distribution of runoff producing areas, which features it as one of the conceptual, semi-distributed hydrological models developed. By comparing with the Pitman model of South Africa, Sacramento model of USA, NAM model of Europe and the SMAR model of Ireland, Gan ${ }^{[4]}$ concluded that the Xinanjiang model did consistently better, even in dry catchments. The model consists of 15 parameters (see Tab.1) and performs best for the humid and semi humid catchments.

All the parameters of Xinanjiang model should be calibrated before application. The hydrological data inputs of the model are areal mean rainfall, and measured pan evaporation. Besides these, sub catchment areas, and initial state of the catchment are necessary for the calculations. A complete description of Xinanjiang model can be found in ${ }^{[2-3]}$,

Tab. 1 Parameters of the Xinanjiang model

\begin{tabular}{lll}
\hline & K & Ratio of potential evapotranspiration to pan evaporation \\
\hline Evapotranspiration & WUM & Tension water capacity of upper layer \\
Parameters & WLM & Tension water capacity of lower layer \\
Runoff Generation & C & Evapotranspiration coefficient of deeper layer \\
Parameters & WM & Areal mean tension water capacity \\
& B & Exponential of the distribution of tension water capacity \\
& IM & Ratio of impervious area to the total area of the basin \\
Runoff Separation & SM & Free water storage capacity \\
Parameters & EX & Exponential of distribution water capacity \\
& KG & Outflow coefficient of free water storage to the ground water flow \\
Runoff Concentration & KI & Outflow coefficient of free water storage to the inter flow \\
Parameters & CG & The recession constant of ground water storage \\
& CI & The recession constant of lower interflow storage \\
Flow Routing Parameter & XE & The recession constant of channel network storage \\
\hline
\end{tabular}

\section{Catchment characteristics}

The Kalu river upper catchment area is about $603 \mathrm{~km}^{2}$ and located in southwest Sri Lanka to the south of the central highlands and lies between $80.40^{\circ}-80.60^{\circ} \mathrm{N}$ latitude and $6.53^{\circ}-6.80^{\circ} \mathrm{E}$ longitude. Elevations vary from about $100 \mathrm{~m}$ to $2225 \mathrm{~m}$ above MSL. Mountain ranges, high peaks, dissected plateaus, and escarpments cover a large part of the area. On average, the slopes vary (depending on their lithology and structure) from about $10^{\circ}$ to $35^{\circ}$ in the upland ridges ${ }^{[5]}$. Due to the geographical location, Kalu river catchment receives rain during both monsoon seasons, from May to June and from September to October. The mean daily values of precipitation, evaporation and discharge at the outlet are $9.58 \mathrm{~mm}, 3.14 \mathrm{~mm}$ and $7.04 \mathrm{~mm}$ respectively. The average 
annual temperature in the catchment ranges from $26.9^{\circ} \mathrm{C}$ to $27.8^{\circ} \mathrm{C}$.

Distribution of soils in the catchment area has close affinity with topography, geology, and climate. Dominant soil types visible in this area are Red Brown Earths and Low Humic Gray soils, Reddish Brown Earths and Immature Brown Loams, Red Yellow Podzolic soils, Bog and Half-bog soils, and alluvial soils. However, nearly $86 \%$ of the area is covered with Red Yellow Podzolic soils ${ }^{[5]}$. The two main vegetation types are tropical rain forests and mountain forests. There are 13 types of land use classes in the catchment as shown in Table 2. About 30.2 percent of the land is used for 'Chena' cultivation ${ }^{[6]}$. Tea and rubber plantations are the other major land uses (see Tab.2).

Tab. 2 Land use classes

Land Use Paddy Tea Rubber Chena Forest Other Plantations Grass Lands Scrub Rock Garden Build- up area

\begin{tabular}{llllllllllll} 
Area $(\%)$ & 4.90 & 14.1 & 17.60 & 30.30 & 18.00 & 1.80 & 0.40 & 0.20 & 0.2 & 12.30 & 0.2 \\
\hline
\end{tabular}

\section{Statistical indices}

Two statistical indices have been used to compare the application results. They are the Nash Sutcliffe coefficient $D_{y}{ }^{[7]}$ and the percentage of total error (\%Err) in each year.

$$
D_{y}^{2}=1-\frac{\sum_{i=1}^{m} w_{i}^{2}\left[Q_{\mathrm{obs} \dot{i}}-Q_{\mathrm{cal}, i}\right]^{2}}{\sum_{i=1}^{m} w_{i}^{2}\left[Q_{\mathrm{obs} \dot{i}}-\bar{Q}_{\mathrm{obs}}\right]^{2}} \quad \text { (1) } \quad \% \operatorname{Err}=\left[\frac{\sum_{i=1}^{m} Q_{\mathrm{obs}, \dot{i}}-\sum_{i=1}^{m} Q_{\mathrm{ca}, i}}{\sum_{i=1}^{m} Q_{\mathrm{obs}, i}}\right] \times 100
$$

Where $Q_{\mathrm{obs}}$ is the daily mean observed discharge, $Q_{\mathrm{obs}}$ is the observed discharge, $Q_{\text {cal }}$ is the calculated discharge, $m$ is the number of time steps in each year and $w_{i}$ is a weighting factor (usually equal weights are used for each year). The \%Err is obtained as a percentage and depending on the sign (positive or negative), the calculated discharge can be lower or higher than the observed discharge.

\section{Results}

\subsection{Application of the SWAT model}

Firstly, the watershed was delineated into $15 \mathrm{sub}$ catchments using a DEM $(100 \mathrm{~m} \times 100 \mathrm{~m}$ cell size) and a digitized river network. The number of sub catchments generated depends on the threshold limit of flow accumulation. SWAT was applied for the period 1987 to 1995 for daily stream flow generation. However we only can compare the results of two years, 1994 and 1995, that are common to the validation period of the Xinanjiang model. The application results are shown in Tab. 3. It is clear that the \%Err (\%Err >9) is quite high for all years indicating that the water balance of the catchment is not modeled correctly. Furthermore, the highest Nash coefficient $\left(D_{y}\right)$ obtained was only $78 \%$ (for 1992). 
Tab. 3 Application results for the SWAT model

\begin{tabular}{cccccc}
\hline FROM & TO & $Q_{\text {obs }}(\mathrm{mm})$ & $Q_{\text {cal }}(\mathrm{mm})$ & $\% E r r$ & $D_{y}$ \\
\hline $1987-01-01$ & $1987-12-31$ & 1820.68 & 1483.14 & 18.54 & 0.720 \\
$1988-01-01$ & $1988-12-31$ & 3230.34 & 2552.17 & 20.99 & 0.703 \\
$1989-01-01$ & $1989-12-31$ & 3050.90 & 2748.81 & 9.90 & 0.762 \\
$1990-01-01$ & $1990-12-31$ & 2260.35 & 1882.36 & 16.72 & 0.774 \\
$1991-01-01$ & $1991-12-31$ & 2095.51 & 1774.94 & 15.30 & 0.759 \\
$1992-01-01$ & $1992-12-31$ & 2451.88 & 2197.66 & 10.37 & 0.782 \\
$1993-01-01$ & $1993-12-31$ & 3404.04 & 2409.87 & 29.21 & 0.763 \\
$1994-01-01$ & $1994-12-31$ & 2105.63 & 1470.10 & 30.18 & 0.715 \\
$1995-01-01$ & $1995-12-31$ & 3039.80 & 2374.73 & 21.88 & 0.705 \\
\hline
\end{tabular}

Tab. 4 Calibration Results for the Xinanjiang Model

\begin{tabular}{cccccc}
\hline FROM & TO & $Q_{\text {obs }}(\mathrm{mm})$ & $Q_{\text {cal }}(\mathrm{mm})$ & $\% E r r$ & $D_{y}$ \\
\hline $1987-01-01$ & $1987-12-31$ & 1820.69 & 1865.74 & -2.48 & 0.853 \\
$1988-01-01$ & $1988-12-31$ & 3230.35 & 3130.72 & 3.08 & 0.848 \\
$1989-01-01$ & $1989-12-31$ & 3050.91 & 2951.33 & 3.26 & 0.946 \\
$1990-01-01$ & $1990-12-31$ & 2260.36 & 2215.43 & 1.99 & 0.901 \\
$1991-01-01$ & $1991-12-31$ & 2095.51 & 2082.39 & 0.63 & 0.862 \\
$1992-01-01$ & $1992-12-31$ & 2451.89 & 2389.63 & 2.54 & 0.919 \\
$1993-01-01$ & $1993-12-31$ & 3404.04 & 3340.35 & 1.87 & 0.908 \\
\hline
\end{tabular}

\subsection{Application of the Xinanjiang model}

Seven years of historical data (1987-1993) were used for calibration and two years of data (1994-1995) were used for verification of the model. All the parameters of the Xinanjiang model have been calibrated using the SCE-UA (Shuffle Complex Evolution) method ${ }^{[6,8-9]}$. SCE parameters were set as follows ${ }^{[10]}$ for the calibration process: $p=40, m=31, q=16, \alpha=1, \beta=31$, where $p$ is the number of complexes, $m$ is the number of points in a complex, $q$ is the number of points in a sub complex, $\alpha$ is the number of consecutive offspring generated by each sub complex, and $\beta$ is the number of evolution steps taken by each complex. The calibration results for the Xinanjiang model are shown in Table 4 and the verification results are shown in Tab. 5. According to these results, the \%Err is much smaller $(-3<\% E r r<4)$ and the Nash coefficient $\left(D_{y}\right)$ is greater than $84 \%$ for all calibration and verification years.

Tab.5 Verification Results for the Xinanjiang Model

\begin{tabular}{cccccc}
\hline FROM & TO & $Q_{\text {obs }}(\mathrm{mm})$ & $Q_{\text {cal }}(\mathrm{mm})$ & $\%$ Err & $D_{y}$ \\
\hline $1994-01-01$ & $1994-12-31$ & 2105.63 & 2070.13 & 1.69 & 0.894 \\
$1995-01-01$ & $1995-12-31$ & 3039.80 & 2980.71 & 1.94 & 0.885 \\
\hline
\end{tabular}




\section{Discussion and conclusions}

Based on the results shown in Tab. 3 to Tab. 5, the performance of the Xinanjiang model is better than the SWAT model for daily river flow predictions of the Kalu river upper catchment in Sri Lanka. Fig. 1 shows that the Xinanjiang model gives a good fit between the observed and calculated discharge hydrographs for the model verification years. \%ERR (in tab. 5) is small $(<2)$ and the Nash coefficient $\left(D_{y}\right)$ is acceptable $(>0.88)$. Thereby it seems that the Xinanjiang watershed model can be successfully applied in humid or semi humid catchments in Sri Lanka for computing river flows. The input data requirement for the Xinanjiang model is much smaller (i.e. precipitation, pan evaporation, and observed discharge). Therefore it is suitable for modeling many catchments where comprehensive data are not readily available.

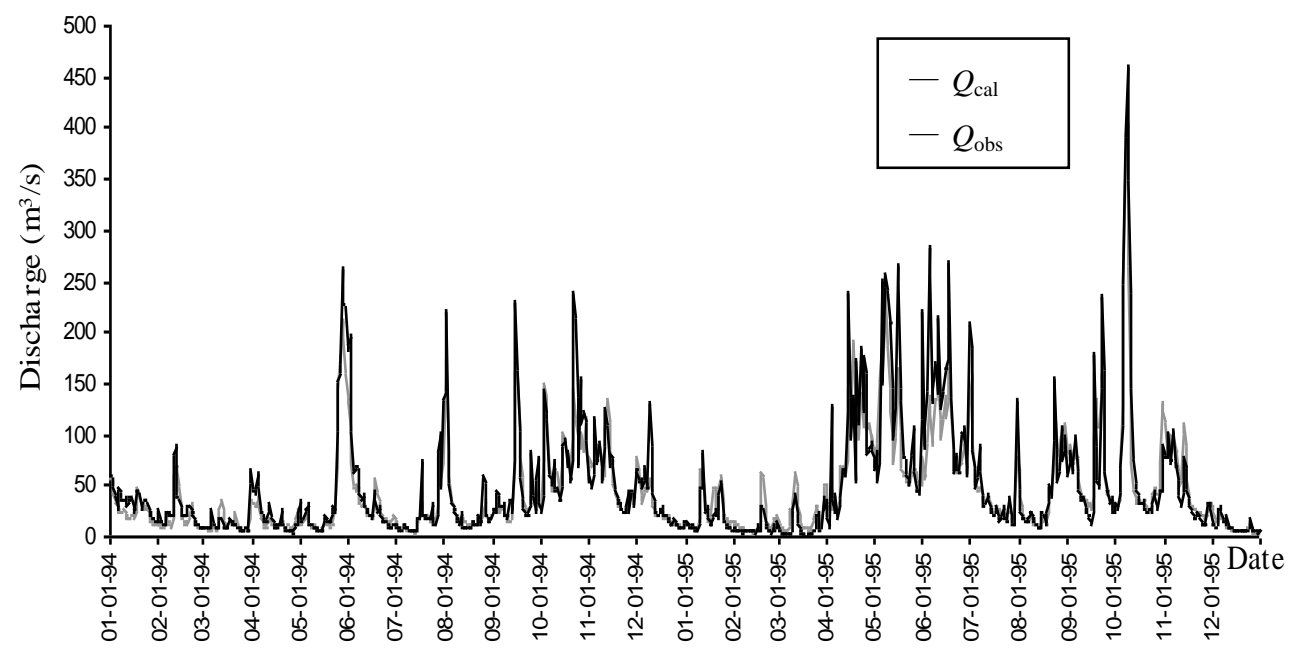

Fig. 1 Discharge hydrographs (verification years) for the Xinanjiang Model

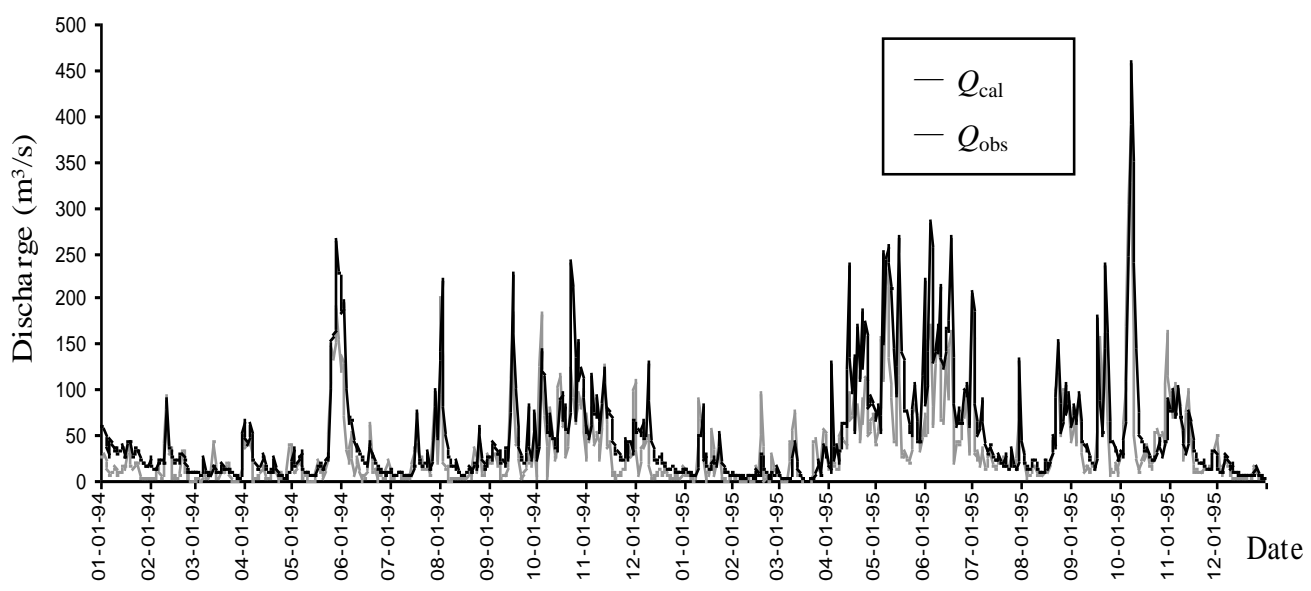

Fig.2 Discharge hydrographs (verification years) for the SWAT Model 
In this study, the performance of the SWAT model was poor compared to the Xinanjiang model. Although the Nash coefficient $\left(D_{y}\right)$ is acceptable (Tab.3), the \%Err is high, indicating that the model is unable to predict accurately the water balance in the catchment. A careful inspection of Tab.3 and Fig. 2 reveal that the calculated discharge is often less than the observed discharge and consequently, \%ERR is positive for each year. It may be partly attributable due to the poor quality and inadequate input data since the output of distributed models strictly depends on the quality of data. The main difficulty of using such distributed models is the higher requirement of input data. For example, in gem mines, water is pumped out continuously and this water adds to the river as surface flow, hence reaches the outlet quicker than ground water flow. In fact this is one reason for lowering the groundwater table. However we were unable to input the pumping data for gem mines. In addition, many people in Sri Lanka use well water for their domestic use. When considering a catchment as a whole, it is not possible to record or count all the individual minor scale water utilizations in detail such as small irrigation, animal husbandry in minor scale, and industrial water utilizations in minor scale. The cumulative value of such water utilizations might be large. The absence of these data makes it difficult to achieve accurate water balance in distributed models. Conceptual watershed models on the other hand can overcome this by adjusting their parameters during calibrating because their parameters have no physical significance. As a result conceptual watershed models show better performance than distributed models where the catchment characteristics and model inputs are limited or incomplete. However distributed watershed models are excellent for understanding the physical processes of the catchment.

Acknowledgement: The support received from the IWMI in data collection and preparation is gratefully acknowledged.

\section{References}

1 Duan Q, Sorooshian S, Gupta V K. Effective and efficient global optimization for conceptual rainfall-runoff models. Wat Resour Res, 1992, 28(4): 1015-1031

2 Duan Q Y, Gupta V K, Sorooshian S. Shuffle complex evolution approach for effective and efficient global minimization. Jour of Opti Theory and App, 1993, 76(3): 501-521

3 Duan Q, Sorooshian S, Gupta V K. Optimal use of SCE-UA global optimization method for calibrating watershed models. Jour of Hydro， 1994， 158: 265-284

4 Gan T Y, Biftu G F. Automatic calibration of conceptual rainfall-runoff models: Optimization algorithms, catchment conditions and model structure. Wat Resour Res, 1996, 32: 3513-3524

5 Hapuarachchi H A P, Li Z J, Ranjit M, et al. Application of global optimization technique for calibrating the Xinanjiang watershed model. Lowland Technology International, 2001, 3: 43-57

6 Karunanayake M M, Katupotha J. An Environmental profile of the Ratnapura district, Technical report, Central environmental authority \& NORAD, Sri Lanka, 1990

7 Nash J E, Sutcliffe J V. River flow forecasting through conceptual models, 1, A discussion of principles. Journal of Hydrology, 1970,10: 282-290 
8 Neitsch S L, Arnold J G, Kiniry J R, et al. SWAT user manual 2000. Grassland, Soil and Water Research laboratory, Agricultural Research Service, USA. 2000

9 Zhao R J, Liu X R. Computer models of watershed hydrology: The Xinanjiang Model, (ed. by Singh V P). Water Resources Publications, Highlands Ranch, Colorado, 1995: 215-232

10 Zhao R J, Zhuang Y L, Fang L R, et al. The Xinanjiang Model. Hydrological Forecasting Proceedings of the Oxford Symposium. IAHS Publ. 1980, 129: 351-356

\title{
SWAT 模型在斯里兰卡河流径流预测中的运用
}

\author{
H. A . Prasantha HAPUARACHCHI ${ }^{1}$, \\ 李致家 ${ }^{1} \&$ Flügel Albert WOLFGANG ${ }^{2}$
}

（1：河海大学水资源环境学院, 南京 210098 ; 2: International Water Management Institute, Battaramulla, Sri Lanka)

\section{摘 要}

本文运用SWAT模型和新安江模型对斯里兰卡卡鲁河流域上游地区日径流进行了预测. 卡鲁河是斯里 兰卡的第二大河，由于流域的降雨量很大，上游地区河流沿峡谷流下，中下游平原地区河床平坦. 卡鲁河 流域的洪水变的很正常. 应用SWAT模型来对卡鲁河的日径流量进行预测, 并同应用新安江模型所得到的结 果做对比. 研究表明, 新安江模型要比SWAT (分布式水文模型) 模型在卡鲁河日径流量预测上稍微好一些. 实际上, 或许数据质量不高或不恰当是部分原因, 因为SWAT的输出成果严格取决于其输入的数据质量. 此 外, 在斯里兰卡, 许多人的日常用水是靠井水. 当把流域看作一个整体, 通常都是一个很大的范围, 那样 的话就不可能详尽的记录所有各个小规模的水利用, 例如: 小灌溉、小规模的家畜管理和工业水利用. 这 些水利用累积起来或许就很可观. 这些数据的缺失对分布式水文模型在水平衡的应用有着独特的影响. 但 是概念水文模型 (如新安江模型) 可以根据实际情况在校正中调节它的参数, 因为这些参数并没有实质 的物理含义. 因此, 在流域特征和模型输入数据有限或不完整的情况下, 概念水文模型比分布式水文模型 更具优势.

关键词 新安江模型 SWAT 模型 概念水文模型 分布式水文模型 径流预测

分类号 P332 